РЕГІОНАЛЬНА ЕКОНОМІКА

UDC 330

I. A. Kosach, Candidate of Economic Sciences, Associate Professor

\section{THE EVALUATION OF THE AGRI- PRODUCTION INITIAL STATE POSITION AS A PRECONDITION OF BUSINESS INTEGRATION BASED ON PUBLIC-PRIVATE PARTNERSHIP}

Urgency of the research. Evaluation of the initial state position AIC to investigate the possibility of introducing publicprivate partnership is a key issue in the context of the integration agro business structures.

Target setting. Currently, the methods that would meet the needs of application of PPPs interaction opportunities in agriculture does not exist.

Actual scientific researches and issues analysis. The fundamentals of relations PPP are provided in the studies of foreign and domestic scientists such as E. Sava, H. Van Ham, J. Kopenyan, V. Pavlyuk, S. Pavlyuk, I. Zapatrina, S. Hryschenko and others.

Uninvestigated parts of general matters defining. In the present circumstances there are no common methodological principles of assessment of precondition implementation of PPP relations and their further development

The research objective. The purpose of the article is to develop a methodological assessment of initial positions of $A P C$ in conditions of public-private partnership, which is a part of comprehensive study of the integrated business structures formation in agriculture based on the public-private partnership.

The statement of basic materials. The features of approaches to the analysis of agricultural production are considered. The functions of analyze of PPP possibilities and feasibility in agriculture are proposed. The system of key indicators assessing the possibilities of forming of integrated business structures in agriculture based of public-private partnerships are proposed in the context of a systematic and synergetic approach.

Conclusions. These approaches constitute a coherent and logical system of analysis of the readiness of agricultural enterprises to integration interaction on the basis of PPP.

Keywords: Integration business structures; integration; public-private partnership; agriculture.
УДК 330

I. А.Косач, к. е. н., доцент

Актуальність теми дослідження. Оцінка вихідних позицій стану АПК з метою дослідження можливостей впровадження державно-приватного партнерства $\epsilon$ актуальним питанням в контексті фрормування інтеграційних підприємницьких агропромислових структур.

Постановка проблеми. На даний час методики, яка б повністю відповідала потребі обгрунтування можливостей застосування взаємодії на основі ДПП в агропромисловому комплексі, не існує.

Аналіз останніх досліджень $і$ публікацій. Основи формування відносин ДПП надано у дослідженнях провідних зарубіжних $і$ вітчизняних вчених таких, як E. Сава, Х. Ван Хем, Ю. Копен ян, В. Павлюк, С. Павлюк, I. Запатріна, С. Грищенко та ін.

Виділення недосліджених частин загальної проблеми. $B$ умовах сьогодення не існує єдиних методичних засад оцінки передумов впровадження відносин ДПП та їхнього подальшого розвитку

Постановка завдання. Метою статmі $\epsilon$ розробка методичних засад оцінки вихідних позицій АПК в умовах становлення державно-приватного партнерства, яка $\epsilon$ складовою частиною комплексного обґрунтування процесів формування інтеграційних підприємницьких структур в АПК на засадах державно-приватного партнерства.

Виклад основного матеріалу. Досліджуються особливості підходів до аналізу стану агропромислового виробництва. Розглянуто функції аналізу можливостей $i$ доцільності застосування ДПП в агропромисловому комплексі. Запропоновано систему основних показників оцінки можливостей формування інтеграційних підприємницьких структур в АПК на засадах державноприватного партнерства в контексті застосування системного та синергетичного підходів.

Висновки. Наведені підходи складають цілісну та логічну систему аналізу ступеня готовності підприємств АПК до інтеграційної взаємодії на засадах ДПП.

Ключові слова: Інтеграційні підприємницькі структури; інтеграція; державно-приватне партнерство; агропромисловий комплекс.

DOI:10.25140/2410-9576-2017-1-2(10)-195-199

Urgency of the research. Public-private partnership (PPP) is one of the most effective forms of cooperation between public and private sectors and is aimed to perform functions related to supporting of innovative development, infrastructure and efficient using of public funds. PPP is an institutional and organizational alliance of the government and private businesses connected with the 


\section{РЕГІОНАЛЬНА ЕКОНОМІКА}

implementation of the important social projects in a wide range of areas such as the development of strategic industries and public services in scale of the whole country or certain areas [4].

Target setting.At present realities the establishment of Ukrainian relations of public-private partnership (PPP) is on the formation stage, which explains the lack of systematic information about the status of this process. Currently, the methods that would meet the needs of application of PPPs interaction opportunities in agriculture does not exist.

Actual scientific researches and issues analysis. The basic theoretical and methodological foundations of PPP relations are given in researches of leading foreign and domestic scientists such as E. Sava, H. Van Ham, J. Kopen yan, I. Zapatrina, S. Hryschenko and others [1-4].

Uninvestigated parts of general matters defining. The problem of interaction between public and private partners in the context of PPP and the formation of integration structures based on PPP relations is quite new and, according to this, there are no common methodological principles of assessment preconditions to study these processes and their further development. So the task of developing methodological approaches to the study of the original level of interaction based on PPP relationship that will detect the conditions of attraction of agricultural enterprises to integration processes such partnership within the existing information.

The research objective. So, the purpose of this research is to develop the methodological principles of agro-industrial initial positions in conditions of public-private partnership, which is the part of a comprehensive study of the integration of business structures in agriculture based on the publicprivate partnership. The objective is to determine the available resources of agroindustrial production and its sub-complexes and possibility of introducing PPP relations and PPP projects as the basis for the formation of agricultural integration business structures.

The statement of basic materials. The experience shows that the using of public-private partnership is a promising direction of economic relations development. For our country, in addition to investment problems, this model can solve economic, political, but also social problem. The exceptional importance of public-private partnerships as an effective tool of implementing of agricultural development policy is determined:

- at first, by the development of agricultural production and infrastructure, according to the interests and the active participation of business,

- at second, by the increasing efficiency of state property and budget funds application allocated for support agriculture;

- at third, by the incentives of private-sector business activity in areas that have the greatest potential for good economic growth.

It is reasonable to point out the following analysis functions that can appropriate the use of PPPs in agriculture:

1) the evaluation function, the content of which is to match the actual performance regulations;

2) the function diagnostics ( it detects the causal connection between the parameters and conditions and environmental factors);

3 ) the function of searching ( the identification of additional reserves and possibilities, as well as the ways to improve the position).

The functions are implemented in the context of problems, which can include:

1) the assessment of agricultural production in the context of food security;

2) the assessment of the environmental factors impact such as a government regulation of agriculture, market conditions, competition, etc;

3 ) the foundation of decisions about the possibilities of implementing the PPP;

4) the assessment of the PPP potential.

We consider the methodical approach of assessing the possibilities of businesses integration forming in agriculture on the basis of public-private partnership (IBASppp). As an information base for the application of the methodology it is proposed to use the official dates of state statistics. There is a certain difficulty to find the relevant information about the state of public-private partnership in agriculture of Ukraine. Therefore, in addition to the information provided by the statistical agencies and 


\section{РЕГІОНАЛЬНА ЕКОНОМІКА}

public authorities we consider the necessity of appropriation to use information from periodical scientific and commercial publications.

An important part of study opportunities of IBASppp forming is the assessment of agricultural production development and its structural components under the influence of internal and external factors. According to this conclusion the results of previously conducted studies will help to evaluate the effectiveness of earlier analytical work, but also take into account the admitted mistakes and shortcomings.

However, we highlight the following areas of researches within which instructional techniques that can be used by us to assess baseline conditions were developed. The most common indicators were proposed by the World Bank in the study of agricultural production and consist of: the agricultural land (percentage of total land area); the agricultural machinery, tractors per $100 \mathrm{~m} 2$ of arable land; the value added in agriculture (as a percentage of GDP); the crop index, the index of livestock, the grain yield (kg per hectare); the employment in agriculture (as a percentage of total employment), the fertilizer consumption (kilograms per hectare of arable land); the index of food production; the land under cereal production (hectares), the rural population (percentage of total population).

For its part, MI Horungij notes that "the agrarian sector of Ukraine can not be regarded as an object in which any changes can be made according to some pattern". The author stresses that regional differences, different degrees of economies, weak state influence on the formation of the outer medium agricultural enterprises must be taken into account [7].

According to some scientists, the efficiency of agro- industrial production is determined by the results of the farmers and small agro- industrial enterprises. For example, the basic imperatives of agricultural production, according to P. Sabluk, is to provide the acceptable performance for the cost of production and improve the product quality and production process [6].

According to the analysis of the main approaches the main analyzed objects are:

1) the dynamic parameters of agro-industrial production;

2) the structural changes in agricultural production;

3) the efficiency indicators of agro-industrial production ;

4) the indicators of food security.

However, such a variety of techniques confirms the absence of agricultural production analysis in terms of the possibility of public-private partnership introducing.

According to the analysis of scientific literature on this issue, we take the responsibility to say that the system factors and parameters that would fully meet the needs of justification of opportunities for application interaction based on PPP in agriculture, currently does not exist. Thus, in our study, we propose to consider the state of agricultural production development as a socio-economic conditions of integration of agro- business structures according to PPP principles using the specific indicators. (Tab. 1)

We proposed a system - synergetic approach to study the above units (Tab. 1). The systemstructural approach enables the researcher to consider the agro-industrial production as an integrated system formed by the structural elements. The purpose of this approach is the development of goals, means, methods and basic directions of the research. The system-functional approach allows the researcher to consider the operation of the system in general and reveals the functional integrity of the agro-industrial production. This approach originates from the formulation of the target instruction and functions of modern agricultural development as a regional system.

From its side, the synergetic approach is appropriate in the case of substantiation of:

- the basic requirements for compliance of the concrete paces of economic development;

- the sectoral indicators of economic dynamics, which is the basis for determining of economic potential of public-private partnerships and further development of IBASppp formation mechanisms;

- the modeling of the trajectory of economic randomness and historical unpredictability development by the influence of endogenous and exogenous factors.

Therefore, the combination of systemic and synergistic approaches principles in the study provides a corresponding multiplier effect and neutralizes or limits the impact of negative factors. In terms of self-organization and self-equilibrium achieving the trajectory of agro-industrial growth production can 


\section{PЕГІОНАЛЬНА ЕКОНОМІКА}

be characterized as the cyclic with certain limit values certifying internal system balance and damping of threats. These values reflect the emergence of a new phase portrait of agriculture. The research of it uses the principles of the system and synergistic approach and allows to justify the possible changes in the dynamics of major economic indicators in accordance to existing risks and threats. For the above position and applying them to the feasibility of forming integration structures based on PPP we observe the following principles:

- consistency that takes into consideration both internal interconnections and interdependencies and reviews the subject of research as a part of the economic system of higher level;

- complexity, which requires the analysis of all components of the research object.

Table 1

The key indicators for assessing the prerequisites for implementation of PPP as the basis for the formation of agricultural integration business structures

\begin{tabular}{|c|c|c|}
\hline $\mathrm{N}$ & The groups (blocks) of indicators & \multicolumn{1}{c|}{ The key indicators } \\
\hline 1 & $\begin{array}{l}\text { The block of agricultural production } \\
\text { estimate }\end{array}$ & $\begin{array}{l}\text { The volume of gross agricultural production; index of } \\
\text { livestock, crop production volume index, the index of } \\
\text { agricultural production; the profitability of agricultural } \\
\text { production; the proportion of agricultural output in GDP; } \\
\text { Code productivity; output of various types of agricultural } \\
\text { products; price indices of agricultural products; land use; } \\
\text { consumption of basic foodstuffs for 1 person; import and } \\
\text { export of agricultural products. }\end{array}$ \\
\hline 2 & $\begin{array}{l}\text { The block of evaluation of large } \\
\text { enterprises and small business for PPP } \\
\text { implementation }\end{array}$ & $\begin{array}{l}\text { The output of major agricultural products agricultural } \\
\text { holdings; Dynamics Land Bank increasing agricultural } \\
\text { holdings; dynamics of world prices for major grains and } \\
\text { oilseeds; the number of farms on }\end{array}$ \\
\hline $\begin{array}{l}\text { the legal form of business; the share ofagricultural } \\
\text { enterprises in the total number of agricultural products; } \\
\text { structure of cooperative associations for areas of activity; } \\
\text { dynamic area of land farms. }\end{array}$ \\
\hline
\end{tabular}

Source: compiled by the author

The essence of the methods that are used in the study can be characterized as follows:

1. A method of system analysis involves the development of common principles and methods for the study of complex objects, in this case - the national agro-industrial production in order to factors of the internal and external environment.

2. A method of balance - it is used to calculate the balance of agri-food products and inputs. Such calculations reveal deficient and excess resources and develop proposals for balancing resources and sustainability of development processes.

3. A monographic method - it is used to study the typical objects making up the total population, and identify causal relationships. This method can study the international experience of PPP implementation in agricultural production.

4. Statistics and economic method - a set of techniques used for the general characteristics of social phenomena through mass digital data.

Using these methods, approaches and indicators in its entirety is method of analysis.

Conclusions. Thus, the approach to assessing the preconditions of agricultural enterprises attracting to the integration process of partner type and analysis of synergistic potential of PPP meet the requirements and objectives for analytical research and in the aggregate constitute a coherent and logical system of analysis of the agricultural enterprises readiness to integration interaction on the basis of public-private partnership.

\section{References}

1. Savas, E. S. (2000). Privatization and Public Private Partnerships, N. Y. : Chatham House Publishers, 2000, pp. 105-106 [in English].

\section{Література}

1. Savas, E. S. Privatization and Public Private Partnerships, N. Y. : Chatham House Publishers, 2000, p. 105-106. 


\section{РЕГІОНАЛЬНА ЕКОНОМІКА}

2. Klijn, E. H., Teisman G. R. (2000). Governing Public-Private Partnerships : Analyzing and Managingthe Processes and Institutional Characteristics of Public-Private Partnerships // Public-Private Partnerships : Theory and Practice in International Perspective / Ed. by S.P, Osborne.London: Routledge, 2000. p. 85 [in English].

3. Gryshchenko, S. (2011). Pidhotovka ta realizatsiya proektiv publichno-pryvatnoho partnerstva: praktychnyy posibnyk dlya orhaniv mistsevoyi vlady ta biznesu [Preparation and implementation of public-private partnership : A practical guide for local authorities and businesses]. / PE Moskalenko O. M., p. 140 [in Ukrainian].

4. Zapatrina, I. V., Lebeda, T. B. (2011). Derzhavnopry vatne partnerstvo yak faktor ekonomichnogo zrostannya ta problemy' jogo rozvy'tku $v$ Ukrayini [Public-private partnership as a factor of economic growth and problems of its development in Ukraine ]. Ekonomist, № 3,- pp. 52-58 [in Ukrainian].

5. Pavlyuk, K. V., Pavlyuk, S. M. (2010). Sutnist $i$ rol derzhavno-pryvatnogo partnerstva $v$ socialnoekonomichnomu rozvytku derzhavy [The essence and role of public-private partnerships in the socio economic development of state]. Scientific works of KNTU.Economic sciences, 2010. - Vyp. A, - pp. 10-19. [in Ukrainian]

6. Sabluk, P. T. (2011). Innovatsiyna model rozvy'tku agrarnogo sektoru ekonomiky Ukrayiny ta rol nauky $v$ yiyi stanovlenni [The innovative model of agrarian sector of Ukraine and the role of science in it's development]. Problemy innovatsiyno-investytsiynogo rozvytku, № 2, - pp. 200-208 [in Ukrainian]

7. Khorunzhyi, M. (1998). Agrarna polityka [The agrarian policy]. Kyiv, p. 240 [in Ukrainian].
2. Klijn, E. H., Teisman, G. R. Governing PublicPrivate Partnerships: Analyzing and Managingthe Processes and Institutional Characteristics of Public-Private Partnerships // Public-Private Partnerships: Theory and Practice in International Perspective / Ed. by S. P, Osborne.London : Routledge, 2000. P. 85.

3. Грищенко, С. Підготовка та реалізація проектів публічно-приватного партнерства: практичний посібник для органів місцевої влади та бізнесу / С. Грищенко. - К. : ФОП Москаленко О. М., 2011. - 140 с.

4. Запатріна, І. В. Державно-приватне партнерство як фактор економічного зростання та проблеми його розвитку в Україні / І. В. Запатріна, Т. Б. Лебеда // Економіст. - 2011. - № 3. - С. 52-58.

5. Павлюк, К. В. Сутність і роль державноприватного партнерства в соціальноекономічному розвитку держави / К. В. Павлюк, С. М. Павлюк // Наукові праці КНТУ. Економічні науки. - 2010. - Вип. А. - С. 10 19.

6. Саблук, П. Т. Інноваційна модель розвитку аграрного сектору економіки України та роль науки в її становленні / П. Т. Саблук // Проблеми інноваційноінвестиційного розвитку. - 2011. - № 2 - С. 200-208.

7. Хорунжий, М. Й. Аграрна політика / М. Й. Хорунжий. - К. : КНЕУ,1998. - 240 с.

\section{Бібліографічний опис для цитування :}

Kosach, I. A. The evaluation of the agri-production initial state position as a precondition of business integration based on public-private partnership / I. A.Коsach // Науковий вісник Полісся. - 2017. - № 2 (10). Ч. 1 . - С. 195-199. 